Article

\title{
Sustainable Tourism Policy, Destination Management and Sustainable Tourism Development: A Moderated-Mediation Model
}

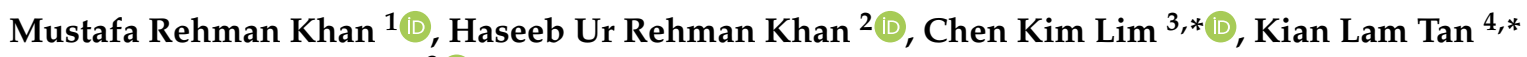 \\ and Minhaz Farid Ahmed ${ }^{3}$ (D) \\ 1 Faculty of Management and Economics (FPE), Universiti Pendidikan Sultan Idris (UPSI), \\ Tanjong Malim 35900, Malaysia; mustafa.r.khan03@gmail.com \\ 2 Faculty of Art, Computing and Creative Industry (FSKIK), Universiti Pendidikan Sultan Idris (UPSI), \\ Tanjong Malim 35900, Malaysia; haseebrkhan6@gmail.com \\ 3 Institute for Environment and Development (LESTARI), Universiti Kebangsaan Malaysia (UKM), \\ Bangi 43600, Malaysia; minhaz@ukm.edu.my \\ 4 School of Digital Technology, Wawasan Open University, 54, Jalan Sultan Ahmad Shah, \\ George Town 10050, Malaysia \\ * Correspondence: kim@ukm.edu.my (C.K.L.); andrewtan@wou.edu.my (K.L.T.)
}

\section{check for}

updates

Citation: Khan, M.R.; Khan, H.U.R.; Lim, C.K.; Tan, K.L.; Ahmed, M.F

Sustainable Tourism Policy,

Destination Management and

Sustainable Tourism Development:

A Moderated-Mediation Model.

Sustainability 2021, 13, 12156.

https://doi.org/10.3390/su132112156

Academic Editors: Dimitrios Aidonis,

Naoum Tsolakis

and Charisios Achillas

Received: 5 October 2021

Accepted: 29 October 2021

Published: 3 November 2021

Publisher's Note: MDPI stays neutral with regard to jurisdictional claims in published maps and institutional affiliations.

Copyright: (c) 2021 by the authors. Licensee MDPI, Basel, Switzerland. This article is an open access article distributed under the terms and conditions of the Creative Commons Attribution (CC BY) license (https:// creativecommons.org/licenses/by/ $4.0 /)$.

\begin{abstract}
In the recent years, the rapid growth of the tourism industry has risen to prominence as a global concern. Tourism empowers communities and uplifts the economy. However, it poses social and environmental challenges, which in turn draws attention to tourism patterns. Sustainable tourism promises protection of the environment and the social-cultural elements of any given destination. Hence, this study aims to understand the complex relationship between sustainability policy, management, and tourist behavior. Thus, we examined the relationships between sustainable tourism policy and destination management, destination social responsibility, and tourist value orientation with sustainable tourism development. We recruited participants at managerial level coming from 163 Malaysian companies and conducted a cross-sectional quantitative study, using partial least square structural equation modeling. We propose that sustainable tourism policy and destination management and destination social responsibility significantly impact sustainable tourism development. Moreover, destination social responsibility partially mediates the relationship between sustainable tourism policy destination management and sustainable tourism development.
\end{abstract}

Keywords: sustainable tourism policy and destination management; destination social responsibility; tourist value orientation; sustainable tourism development

\section{Introduction}

International tourist arrivals are expected to reach 1.8 billion by 2030 [1]. Due to the prediction, sustainability is the main concern for authorities all over the world. The Asia Pacific region received 25\% of the world's total tourists in 2018 with $7 \%$ regional growth in tourism expenditure, which in turn accounted for 30\% of global tourism [2]. International tourist arrivals in Southeast Asia grew by 7\% in 2018, with 5\% growth in tourism receipts [2]. Moreover, in 2018, Malaysia, famous for its islands and coastline, ranked third-largest economy with tourism as a key economic pillar [3]. Currently, the world and the entire tourism industry face the COVID-19 pandemic that significantly influenced global tourism. At the present time of the COVID-19 pandemic, the importance of tourism and its sustainable development is extremely important [4]. The sustainable development of tourism creates a link between needs of local, natural resources and tourism [4,5]. Therefore, sustainability initiatives are crucial for communal economies [6].

The COVID-19 has had a detrimental effect on people's livelihoods and economies worldwide. Social, economic, religious, and cultural activities have been interrupted throughout this epidemic. Numerous researchers have highlighted the need of doing a 
comprehensive study on COVID-19 and its economic and social consequences [7]. Consequently, addressing sustainable tourism is critical, as dealing with COVID-19 pandemic impacts is a part of dealing with sustainability [8]. From a sustainability perspective, past research papers suggested many sustainable tourism models hinge upon an understanding of communal costs and benefits. For example, tourism provides benefits to local communities, however, it also generates negative environmental, social, and cultural effects [9]. Consequently, researchers have focused on ways of mitigating the harmful effects of tourism on host destinations [10-13]. Tourism destinations rely on cultural and environmental resources. Thus, it is required to emphasize socially responsible practices to stimulate tourism as well as protect the degradation of natural resources $[14,15]$. Corporate social responsibility (CSR) bears significance to the tourism industry [16]. Socially responsible behavior of organizations performs a substantial role in achieving sustainable development of destinations [17] and in terms of protecting natural resources, culture, environment, and economy of local communities $[18,19]$. Local communities of tourist destinations consider the impact of tourism as an accumulation of the activities performed by all stakeholders in that location [20]. Subsequently, [17] (p. 309) specify that "destination social responsibility (DSR) includes stakeholder activities that protect and improve the social and environmental interests of an entire destination, in addition to the economic interests of the individual organizations". Hence, destination-competitive development facilitates the protection of natural and cultural resources and improves the wellbeing of the local communities [21].

Destination management organization (DMO) roles are inevitable in tourism management and development. Past researchers emphasized that planning and management are crucial for tourism development [22,23]. Moreover, to achieve sustainability, tourism destinations should design appropriate policies for their sustainable development $[22,23]$. On the other hand, environmental and cultural resources are essential factors for the development of a tourism destination, therefore, these resources should be managed and developed responsibly through sustainable tourism policy and destination management (STPDM) $[20,21,24]$. It has been established that socially responsible practices of tourism destinations contribute to sustainable development [17].

Although scholars have focused on STD [25-27], little attention is paid to its links with the social responsibility of destination [28,29], and tourism policy and management [21,24]. Moreover, efficient policies, destination management, and stakeholders' responsibility play a substantial role in mitigating inevitable problems related to tourism activities [30]. Furthermore, pro-environmental behavior of tourists ensures a destination's long-term tourism attractiveness and economic viability [31]. Subsequently, the present paper proposes insights on STPDM and DSR as antecedents of STD with the moderating factor of tourist value orientation (TVO) that measures tourists' anti-environmental behavior functions for sustainable development. STPDM has potential to maximize economic development while improving destination competitiveness [24]. Similarly, DSR can improve positive tourism impact on local communities [19]. Moreover, this study focuses on Langkawi and Penang Islands-Popular tourist destinations, located in the northwest of Malaysia-A suitable context to research the complexities of growing tourism and sustainability [32].

Despite considerable research, sustainable tourism development is a dynamic process that is constantly faced with new challenges [33]. Hence, the topicality of the research is timely because numerous scientists have identified significant challenges for sustainable tourism as a result of rapid growth in tourism sector [34,35], however, there is currently a lack of sustainability as a result of such rapid growth resulting in unsustainable solutions in the tourism sector. Moreover, in various tourist destinations, different kinds of COVID-19 related crises are resolving and tourists' destinations are re-opening for international tourists [36]. Though, international tourism is expected to return to pre-pandemic 2019 levels by 2024 or later [37]. Thus, developing sustainable tourism strategies is critical to fostering resilience prior to the restoration of international demand. The article discusses the major difficulties of STD and offers some suggestions for the potential con- 
solidation of sustainable destination management, DSR, and sustainable development of tourist destinations.

The remainder of this paper is structured as follows. First, we review the extant literature that led to the development of our hypotheses. Second, we present our methodology, followed by analysis. Fourth, we discuss our results in light of theory development and managerial implications. Finally, we conclude with limitations and avenues for future research.

\section{Literature Review}

The majority of tourism literature was written from the 1960s onward, specifically with the growth of tourism [38]. Scholars have extensively shown the connection between tourism and development theories in an evolutionary manner, using well-known development theories, such as modernization, dependence, neo-liberalism, and sustainable development $[39,40]$. Tourism has often been framed as contradictory to the nature of sustainable development [41,42]. Conversely, Mbaiwa [43] argues that applying the concept of sustainable tourism to practice, has potential to resolve adverse effects of the tourism industry. Sustainable tourism is defined as "a positive approach intended to reduce the tensions and friction created by the complex interactions between the tourism industry, visitors, the environment and the communities which are host to holidaymakers" [44] (p. 2). Sustainable tourism contributes to the development and long-term sustainability of the tourist industry $[45,46]$. Therefore, STD can be considered as tourism development that contributes significantly to the process of development or, at least, do not contradict the maintenance of the principles of development in an indefinite time without compromising the ability of future generations to satisfy their own needs and desires [47]. Consequently, sustainable tourism policies, destination management, and monitoring are important factors in improving community wellbeing, preventing the misuse of natural resources, and providing a better tourism experience [21].

Many sociological theories have been utilized to study the complexities of tourism. For instance, tourist behavior has been linked to emotional solidarity theory [48], communal involvement, social representation theory [49], and social disruption theory [50]. Hence, there is an evident lack of consensus on a single theoretical approach regarding the most predictive power in examining sustainable tourism. However, research on sustainable tourism is dominated by the theoretical foundation of SET [10,51-53], since the SET suggests that residents who support sustainable development tend to be benefit-oriented [54]. Residents live in the destination for a long time and they have to experience consistent changes in their lives under protean tourism-related situations, thus, residents are crucial stakeholders of a destination [54].

SET postulates that individuals, groups, and organizations exchange resources through interactions [51]. These interactions are mainly based on procedures to offer each other valuable resources, which can be considered as an exchange of resources between individuals, groups, and organizations. The resources are subject to social exchange, maybe material, social, or even psychological [51]. Typically, theoretical approaches to examining communal support for tourism development have employed communal advantages [6,55]. Researchers claim that anticipated benefits are the main reasons for supporting STD [10-12]. Their basic premise is that, with the rise in adverse impacts of tourism, community support for tourism decreases. Taking into account the trade-off between positive (benefits) and negative (costs) effects of tourism, the SET has often been used to justify communal support for STD [56].

In the context of the present study, stakeholders who realize the advantages of sustainable tourism could actively contribute to its development. Moreover, stakeholders may willingly get involved in an exchange interaction to pursue sustainable tourism as something of value $[10,53]$. Local communities are more likely to abandon their participation in such an exchange, if they perceive associated risks of sustainable tourism surpass the advantages, which negatively affect the host community's support for STD. Hence, SET evaluates effective policy and management regarding tourism development influenced by 
exchange interaction. Accordingly, the extant literature is abundant in studies reliant on SET and its link to other concepts, such as communal support of tourism [57], communal participation, and empowerment [52,58], community involvement [11], tourism policy, residents' attitude, and environmental sustainability [59], sustainability practices and policy adoption [60], environmentally responsible behavior [19], and host-tourist interaction [61].

Further, stakeholder theory (ST) can explain various aspects of tourism related to policies, procedures, culture, tourism development, and management [62]. ST, proposed by Freeman [63], offers management and organizational framework for tourism. Many authors have emphasized the importance of ST in sustainable tourism management $[64,65]$. ST has lately been used in tourism research, focusing on identifying stakeholders and boosting collaboration in tourism planning and development [64,66-68]. Stakeholder participation is a key factor of effective sustainable tourism. Local communities with greater degrees of interest or participation favor sustainable tourism and perceive economic and social benefits of sustainable tourism [69]. Moreover, Byrd [64] emphasized that stakeholder participation promotes success of sustainable tourism.

Eslami et al. [10] extend the model of community involvement proposed by Lee [11], to investigate STD in the context of Malaysia. The model relies on different elements including community attachment, perceived impacts of tourism, quality of life, and STD. These authors assert that improved quality of life induces community support for STD, which alludes to the transactional nature of motivations for sustainability efforts [10]. Similarly, Cheng et al. [6] have offered a pioneering insight by investigating the effect of communal involvement in both residents' attitudes and their personal environmentally responsible behavior toward STD. The study reveals that community involvement and environmentally responsible behavior positively influence STD. Further, these researchers suggest a mechanism based on sustainable policies and management to encourage STD. Islam et al. [60] suggest that tourism organizations should reconsider their policy and operational practices for sustainable development by ensuring economic aspects and by facilitating social well-being, especially, in countries where crowded tourist destinations are environmentally adverse.

On the other hand, previous studies have suggested that communal involvement plays a significant role in STD and provides opportunities for communities to improve their socio-economic and environmental wellbeing [9,19]. Subsequently, residents' involvement is a crucial element for effective planning and management of tourism destinations. Thus, the tourism industry needs to understand what their resident counterparts require from the development of their site for preventing extra economic, environmental, and social burdens, to carrying capacity of destination [70].

\section{Hypotheses Development}

The concept of destination management was introduced in tourism literature during the 1980s, and further improved in the late 1990s [71]. Destination management is the process of bringing together and integrating various components of the destination mix within a certain geographic area, in line with well-defined tourism strategies [72]. Destination management is widely considered as a critical factor in determining destination competitiveness [73]. Destination competitiveness has been evaluated through market share and frequency of tourist visits and it largely omits sustainability concerns [70]. A competitive destination, on the other hand, is a sustainable tourism destination where environmental and social values are protected, alongside economic ones [24]. Competitive destinations are seen to provide better tourism experience in comparison to other destinations [74]. Moreover, destination competitiveness is defined as "what makes a tourism destination truly competitive is its ability to increase tourism expenditure, to increasingly attract visitors, while providing them with satisfying, memorable experiences, and to do so in a profitable way, while enhancing the well-being of destination residents and preserving the natural capital of the destination for future generations" [75] (p. 2). Hence, STPDM emphasizes optimizing economic growth while simultaneously enhancing the attractiveness of destina- 
tions. Thus, a sustainable competitive destination not only serves tourists' needs, protects local environmental, and cultural resources, but also improves the economic and social wellbeing of communities [24].

Sustainable tourism calls for careful management [76] and destination sustainable competitiveness $[17,19,29]$. Dwyer et al. [74] highlight the importance of demand management to sustain destination competitiveness. Moreover, a competitive destination enhances long-term well-being of the local communities [77]. Subsequently, local communities' participation in tourism activities improves sustainable development [24]. From this perspective, sustainable tourism policies, planning, and management are not outcomes, but vehicles for STD.

Tourism policy and destination management appropriately depict attributes of destination competitiveness in terms of experience, knowledge, and information related to concerns of tourism stakeholders [78]. Residents' involvement with tourism enhances the positive impact of tourism on destination communities $[79,80]$, whereas, lack of residents support hinders tourism development $[13,52,57]$.

Further, tourism should protect sociocultural values, customs, natural heritage, and society of tourism destinations against degradation impact [58,81]. Therefore, a tourismreliant economy should develop sustainable tourism to meet residents' needs. Falatoonitoosi et al. [82] revealed that STD positively links to environmental quality, sociocultural empowerment, economic growth, quality of life, and tourist satisfaction. STD provides better tourism experience and promotes tourist-resident cooperation. Consequently, it is crucial to implement sustainability in tourism, which potentially contributes to the community economy [56] while maintaining a balance between social, economic, and environmental concerns [6]. Additionally, researchers proposed a model to analyze destination competitiveness based on influencing factors of the tourism industry including tourist policies, which are related to managing destinations [83]. Hence, sustainable tourism cannot be achieved without appropriate policies and management [21,24]. Therefore, we theorize a causal link and propose the following hypotheses:

Null Hypothesis $\mathbf{1}\left(\mathbf{H 1}_{\mathbf{o}}\right)$. STPDM will have no significant influence on STD.

Alternative Hypothesis $\mathbf{1}\left(\mathbf{H 1}_{\mathbf{a}}\right)$. STPDM will positively influence STD.

A tourism destination is a geographical area with the experience required for tourists to come and stay, with both amenities and infrastructure [84]. A destination's success is not limited to the earning of the commercial side of its stakeholders but is rooted in the wider potential of a destination to boost the social and economic well-being of local communities $[85,86]$. Simultaneously, the development of a destination relies on alliances, cooperation, and coordination between stakeholders and the host community as the region's political, economic, cultural, social, and environmental sustainability is affected [57,85-87].

Given the value of communal support and stakeholders in the tourism industry [71], tourism priorities in the other industries and within the local communities are seen by the organizations responsible for managing a destination [88]. These DMOs are required to play a broader role in society's STPDM: e.g., tourism development planning; management and monitoring; partnering with experts and advancing partnerships among local-tourist businesses; as well as engaging environmental and cultural champions, and tourism advocates [21,71]. Policy and management of destinations are typically assigned to a delegated DMO within the area. This may be an independent or multifunctional organization [89]. Their governance structures vary from municipal authorities to public-private collaboration frameworks. More precisely, "[a] DMO is the leading organizational entity which may encompass the various authorities, stakeholders, and professionals and facilitates tourism sector partnerships towards a collective destination vision" [90] (p.12). 
Tourism literature indicates that the development of tourism destinations can have negative economic, social, and environmental consequences [91-93]. Increased tourism, for example, could cause a rise in the price of commodities in the region, undermine existing culture, and increase crime and conflict $[20,91]$. Moreover, increased tourism activities could have negative environmental impacts, such as air and water contamination, accelerated habitat degradation, overcrowding, and wetland degradation [18,91]. Consequently, in all kinds of destinations, the economic gains for the local communities and the minimization of negative environmental and socio-cultural effects should be complementary objectives, and to achieve these objectives it is crucial to design and implement sustainable tourism policies to manage and control activities of tourism destinations [21,24]. In this regard, DSR is likely to protect the economic, social, and environmental aspects, as well as secure interests and rights of stakeholders. DSR implies that decisions should be based on ethical principles, and outcomes should be above the appropriate performance levels as prescribed by regulatory criteria [29]. It is therefore hypothesized that the STPDM could have a positive relationship with the DSR. Thus, we formulate that:

Null Hypothesis $\mathbf{2}\left(\mathbf{H} \mathbf{2}_{\mathbf{o}}\right)$. STPDM will have no significant influence on DSR.

\section{Alternative Hypothesis $\mathbf{2}\left(\mathbf{H} \mathbf{2}_{\mathbf{a}}\right)$. STPDM will positively influence DSR.}

Recently, an increasing number of researchers have been focusing on tourism destinations and CSR $[19,53,94]$. CSR is a useful approach to study organizational behavior; however, it is not completely suitable in the destination context [20].

DSR extends the concept of CSR in the context of tourism by concentrating on environmental, economic, stakeholder social, and voluntary dimensions of destination. DSR has been defined as "the collective ideology and efforts of destination stakeholders to conduct socially responsible activities as perceived by residents" [20] (p. 3). Hence, DSR pertains to activities in tourism destinations that reduce economic, social, and environmental imbalances. It also sets social standards such as to protect working conditions and cultural heritage, as well as environmental standards to harness natural resources and protect destination diversity [19].

DSR has been examined with a variety of constructs in antecedents and consequent setting including, economic development, community identification [53], community commitment [94], environmentally responsible behavior [17,19], trust [53], community satisfaction [94], quality of life [20], destination sustainability [55] and tourism development $[28,95]$. However, the relationships between STPDM, DSR, and STD, are less clear.

Previous studies confirm that tourism destinations have initiated social responsibility practices such as involving the communities in tourism activities, public relationships, environmental initiatives, and sustainability management [19,96]. DSR is proven to improve destination competitiveness and promote sustainable development of tourism destinations [15]. Additionally, DSR significantly influences community support for tourism development [19]. Globally, stakeholders of the tourism industry had raised concerns to transform tourism activities in congruence with sustainability principles [15]. Sustainable management of tourism destinations creates a balance between environmental, social, and economic considerations [95].

Subsequently, DSR encourages stakeholders to contribute to economic development while being committed to their immediate community and society at large. As the tourism industry has far-reaching negative socio-cultural and environmental impacts, the implementation of sustainable policies is necessary not only to eradicate immediate environmental and socio-cultural issues [6,97] but also to aid long-term sustainability in the tourism industry. DSR is a strategy to improve sustainability, as it obligates organizations to perform in a sustainable way to interest of communities and society as a whole [17]. Moreover, Su et al. [53] highlight the key role of destination development induced by better management and strategic planning, potentially leading toward sustainable development of the tourism industry. Subsequently, organizational involvement in socially responsible 
practices contributes to the welfare of the local communities [19]. DSR could improve the quality of the relationship between the destination and its residents, which could boost economic efficiency, as well as the effect of tourism activities on the environment, socio-culture, stakeholders, and most other members of the community sphere [53]. Then, residents could contribute in a constructive way to support STD, as suggested in the SET. Additionally, grounding their argument in SET, Su et al. [19] propose that socially responsible practices promote communal support for tourism development. Moreover, researchers confirm that DSR significantly influences residents' perception of tourism impact, environmentally friendly behavior, and overall communal satisfaction, which potentially improves sustainable development in tourism destinations $[17,19]$. Hence, we articulate the following hypotheses:

Null Hypothesis $\mathbf{3}\left(\mathbf{H} 3_{\mathbf{0}}\right)$. DSR will have no significant influence on STD.

Alternative Hypothesis $\mathbf{3}\left(\mathbf{H} 3_{\mathbf{a}}\right)$. DSR will positively influence STD.

Null Hypothesis $\left.4 \mathbf{( H 4} \mathbf{H}_{\mathbf{o}}\right)$. DSR will not mediate the relationship between STPDM and STD.

Alternative Hypothesis $\mathbf{4}\left(\mathbf{H 4}_{\mathbf{a}}\right)$. DSR will mediate the relationship between STPDM and STD.

Pro-environmental behavior of tourists is beneficial to host communities as it enhances destination competitiveness, environmental protection, and economic vitality [98,99]. Proenvironmental attitude is enhanced by emotional connection to animals, plants, and the natural environment of a given destination and is informed by individual value systems [100]. Qu et al. [31] developed an obstructive tourism value orientation scale by taking forward the work of Chubchuwong et al. [98] to gauge tourists' anti-environmental behavior. Researchers identified two aspects of TVO, i.e., safeguarding tourism functions and lacking a sense of responsibility [31]. The first aspect, safeguarding tourism functions, comprises different elements including the joy of traveling as liberation from daily routines [101]. Tourists can freely consume destination resources, regarded as paid products and services [99], and environmental concerns add extra obligations to the vacations [98]. These elements induce tourists to feel unobligated to be responsible due to their tendency to dilute the core purpose of traveling. The second aspect, lack of responsibility includes elements such as tourists having no interest in environmental responsibility for tourism destinations due to the short duration of their stay [99].

Tourists have interest in many environmentally unfriendly activities, however, not all of their actions are conscious [102]. Several psychological and neuroscience research results show that individuals can physiologically adapt to a situation and make a decision long before the consciousness begins its assessment [103]. In line with the Johari window, self-knowledge is limited [104], tourists perform many actions unconsciously without realizing their actions and effect on the host community.

Qu et al. [31] highlight that tourists with different levels of value orientation have variations in their resistance intensity to transform a pro-environmental attitude. High impediments encountered and high environmental activation frustration are possibly linked with enhanced tourists' value orientation level. Previous research has supported the role of TVO as a moderating function, given its significant influence on environmental activities. TVO is used to measure tourists' attitude functions for sustainable development [31].

Since, the majority of tourists believe that they have the right to do anything for the money they spend on holidays [105]. Therefore, an increasing number of studies have shown concern about the misbehavior of tourists [106]. Several studies examine tourists' misbehavior from tourists' perspective [106,107], however, limited studies have examined tourists' behavior from the perspectives of managers [108,109]. Hence, this study gauges TVO from the perspective of resident managers. Further, the present research conducts a moderated-mediation analysis because of the existence of both mediation and moderation in the same study [110]. Additionally, Su et al. [19] identify the relationship between 
tourism development, DSR, and environmental value orientation. Hence, the following hypotheses have been developed:

Null Hypothesis $\mathbf{5}\left(\mathbf{H} \mathbf{5}_{\mathbf{o}}\right)$. TVO will not moderate the relationship between STPDM and STD.

Alternative Hypothesis $\mathbf{5}\left(\mathbf{H 5}_{\mathbf{a}}\right)$. TVO moderates the relationship between STPDM and STD. A higher level of TVO negatively moderates the relationship.

Null Hypothesis $\mathbf{6}\left(\mathbf{H 6}_{\mathbf{o}}\right)$. TVO will not moderate the relationship between DSR and STD.

Alternative Hypothesis $\mathbf{6}\left(\mathbf{H 6}_{\mathbf{a}}\right)$. TVO moderates the relationship between DSR and STD. A higher level of TVO negatively moderates the relationship.

Hinging upon SET, this research presents a model to demonstrate the direct impact of STPDM on STD and depicts indirect effect through DSR. Moreover, TVO examines as a moderator in the STD model, shown in Figure 1.

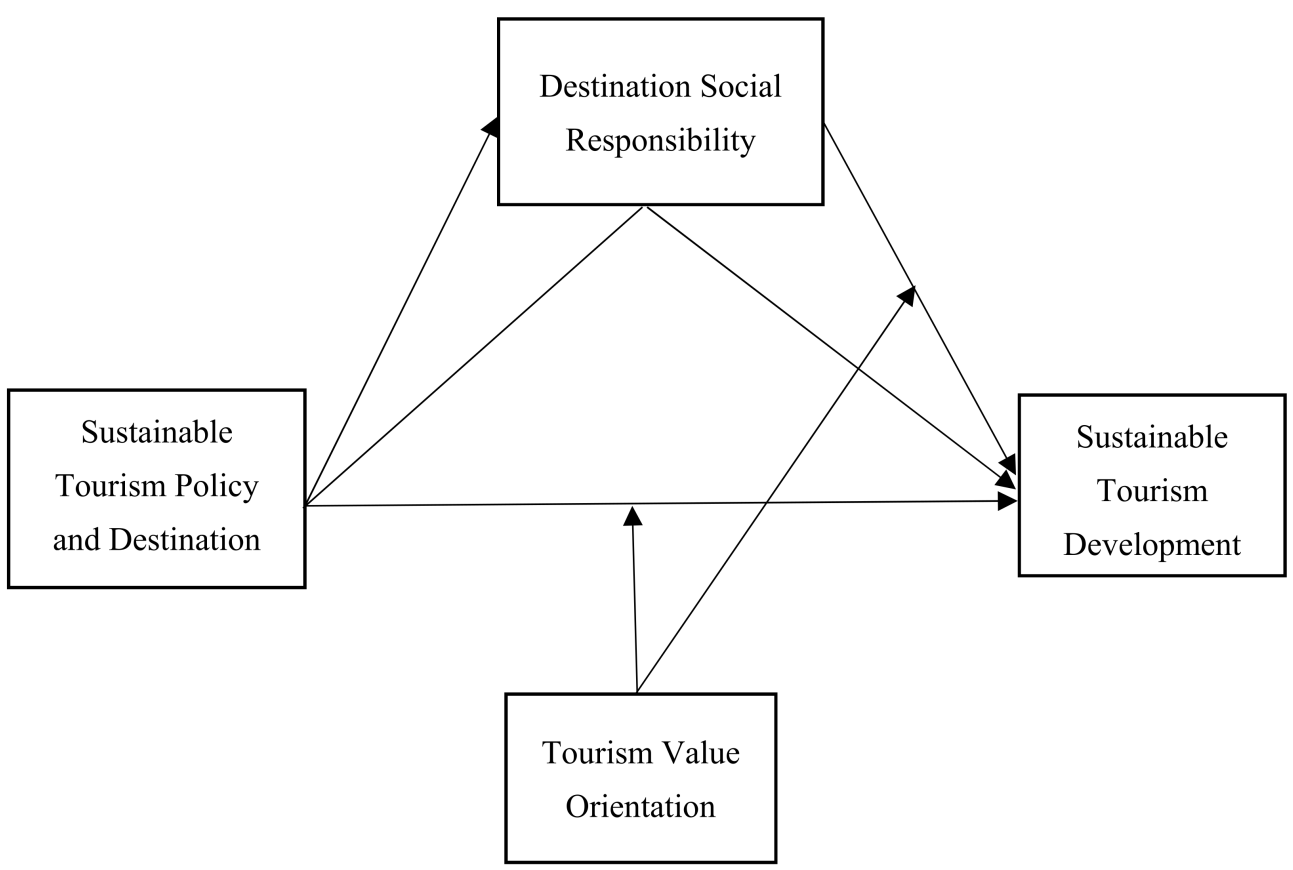

Figure 1. Research model.

\section{Methodology}

\subsection{Study Location, Sampling, and Data Collection}

Tourism is one of the fastest growing industries in Malaysia [111]. In 2018, the tourism industry amounted to around 5.9 percent of the Malaysian GDP, meaning tourism was the third biggest contributor to the national GDP [112]. After the Malaysian Tourism Strategy was introduced in 1992, its steady growth has prompted the government to aggressively explore a variety of new elements [113]. Ecotourism has been described under this strategy as a mode of tourism to be prioritized and extended. A more comprehensive National Ecotourism Strategy 1996 [114], followed shortly, as did the following National Ecotourism Strategy (2016-2025) that offers a general context for the creation and utilization of the future ecotourism of the country [115]. Additionally, the Malaysian government introduced destination management projects such as Langkawi Blueprint 2011-2015 (collaboration program between state agencies, public and private sector for tourism development) and Local Agenda 21 (STD program for local authority), to initiate environmental conservation activities and sustainable tourism. 
This study was conducted in the northwest of Malaysia on Langkawi and Penang Islands where 507 tourism companies operate [116]. Considering the specific goal of this research, data were collected from a sample of people in executive positions, namely managers of tourism companies. However, in engaging them explicitly, we also marginalized other stakeholders, such as the service-users-the tourists themselves. Recognition and inclusion of stakeholders' perspectives can lead to a more comprehensive analysis; however, it has been established that managers have a deep understanding of tourism policy, DSR, and sustainable development [78]. Our choice of respondents stems from several reasons. First, managers, as those surveyed, have accurate knowledge of the specifics of a given destination, more so than tourists and other stakeholders. Second, they have a deep understanding of tourists' behavior. Tourists might have a better assessment of the quality of tourism services, destinations attractions, and resources. However, destination tourism policy, social responsibility, and sustainable development evaluation required a wider viewpoint about the general business environment, social elements, management, policy, and destination issues, which are beyond traditional tourists' attributes [78]. Third, tourists are more concerned about the attractiveness of the destinations as compared to the policy, management, and social responsibility, or other supporting factors of STD. Thus, their focus on destination attractiveness may have an impact on their evaluation, which could be influenced by their set of preferences. Finally, managers at tourism companies are all residents and live in Langkawi/Penang Island, therefore, they are bound to be more concerned about the development of the tourism industry and its subsequent impacts [22].

Managers are recognized as valuable contributors and are perceived to play a crucial role in reviewing, identifying, and supporting various initiatives $[117,118]$. Thus, the managers' perception may provide an actual understanding of tourists' anti-environment behavior on tourism destinations. On the other hand, tourists' misbehavior is noticed globally $[105,106]$, however, tourists are unable to see their blind self, i.e., unknown to self and known to others [104], and unknowingly involve in anti-environmental behavior. Hence, this study provides novel insight into tourists' environment un-friendly behavior from the perspective of managers. Researchers also highlighted scare studies have examined tourists' behavior from the perspective of managers [108,109]. Additionally, TVO had not yet been examined based on their actions from the perspective of managers.

In light of all this, we chose to narrow down our respondent sample to managers. We also collected data about TVO from managers based on their observation of tourist behavior. Further, several researchers recommend a minimum sample size of 100-200 or five cases per free parameter in the model $[119,120]$, however, these general rules require cautious attention [121]. A growing number of researchers start using model-based methods for sample size calculation, with methods based on fit indices or power analysis of the model [121]. Therefore, in this study, the Gefen et al. [122] a priori F-test was performed using $G^{*}$ Power v.3.1.9.2 [123] to determine the minimum sample size, i.e., 158 respondents, required for empirically validating the proposed model.

We used a random sampling approach via searching the survey areas and companies on internet to include managers from tourism companies by paying visits to their offices. After explaining the purpose of the research, managers were asked to participate in the survey. Upon their acceptance of voluntary participation, questionnaires were handed over to managers and sufficient time was provided to fill them and, in many cases, questionnaires were collected on another day. The data collection took place between August and September 2019 with the use of self-administered questionnaires. A research team, including students who received appropriate training prior to their involvement, visited 265 tourism companies and distributed questionnaires to managers. The Hair et al. [124] guidelines were followed for data screening criteria, questionnaires with $5 \%$ or more missing data were removed, and respondents who answered all questions using the same scale were also excluded (also known as straight-lining). The response rate was $61.5 \%$, a total of 163 questionnaires were retained for analysis. 


\subsection{Measures}

The questionnaire was professionally translated into Malay language, further, assistance of field experts had taken for questionnaire face validity before data collection. All constructs were adopted from previous studies to create a questionnaire that consisted of five parts. The first part inquired demographic information of the respondents, such as gender, age, education level, and work experience, presented in Table 1, other parts gauge the variables, including; STPDM, DSR, TVO, and STD.

Table 1. Demographic characteristics.

\begin{tabular}{lcc}
\hline Demographic Characteristics & Frequency & Percentage $\%$ \\
\hline Gender & & \\
\hline Male & 126 & 77.3 \\
Female & 37 & 22.7 \\
\hline Age & & \\
\hline$<25$ & 9 & 5.5 \\
$25-35$ & 94 & 57.7 \\
$36-45$ & 46 & 28.2 \\
$>45$ & 14 & 8.6 \\
\hline Education Level & & \\
\hline High School & 21 & 12.9 \\
Diploma & 85 & 52.1 \\
Degree & 49 & 30.1 \\
Master & 8 & 4.9 \\
\hline Tourism-based Work & & \\
Experience & & 1.8 \\
\hline$<5$ & 3 & 48.5 \\
$5-10$ & 79 & 38.0 \\
$10-15$ & 62 & 11.7 \\
$>15$ & 19 &
\end{tabular}

The questionnaire was based on a five-point Likert scale from $1=$ highly disagree to $5=$ highly agree. In the second part of the questionnaire, the STPDM construct was measured using seventeen items adopted from [21]. Respondents were asked about the public sector commitment to reduce negative environmental and social impact of tourism, collaboration among public and private sectors for local tourism development, destination management, and monitoring of tourism destinations. The third part of the questionnaire measured STD construct using six items adopted from [10]. Respondents were asked about tourism planning and development to sustain economic, social, and environmental standards of tourism destinations. In the fourth part of the questionnaire, DSR construct was gauged using the five-item scale created by [19]. Respondents were asked about public sector concerns for environment, community, economy, stakeholders, and voluntary services. The fifth part of the questionnaire deals with the measurement of TVO by using the five-item scale created by [31]. Respondents were inquired about tourist attitudes and behavior for resources of destination.

\section{Results and Interpretation}

\subsection{Measurement Model}

The analytical results of measurement model obtained for validity and reliability of each construct fulfill the recommended criteria for both the factors, average variance extracted (AVE) is $>0.50$ and the value of Jöreskog's rho $\left(\rho_{c}\right)$ is $>0.70[125,126]$. Individual indicator reliability is considered adequate when the indicator has a factor loading greater than 0.7 on its respective construct [127]. All the items for each construct were loaded on their respective factor and no cross-loadings were found. Each of our item loadings is above 0.7 , results are shown in Table 2. 
Table 2. Results of measurement model.

\begin{tabular}{|c|c|c|c|c|c|c|}
\hline Construct & Source & Item & Item Coding & Loading & Jöreskog's rho $\left(\rho_{c}\right)$ & AVE \\
\hline \multirow{18}{*}{$\begin{array}{l}\text { Sustainable Tourism } \\
\text { Policy and Destination } \\
\text { Management (STPDM) }\end{array}$} & \multirow{18}{*}[21]{} & $\begin{array}{l}\text { "Public sector commitment to } \\
\text { minimizing the negative } \\
\text { environmental impacts of tourism". }\end{array}$ & STPDM1 & 0.835 & \multirow{18}{*}{0.892} & \multirow{18}{*}{0.824} \\
\hline & & $\begin{array}{l}\text { "Importance of integrated approach } \\
\text { to tourism planning". }\end{array}$ & STPDM 2 & 0.836 & & \\
\hline & & $\begin{array}{l}\text { "Political commitment to tourism". } \\
\text { "Public sector commitment to }\end{array}$ & STPDM 3 & 0.810 & & \\
\hline & & $\begin{array}{l}\text { minimizing the negative social } \\
\text { impacts of tourism on the } \\
\text { local community". }\end{array}$ & STPDM 4 & 0.814 & & \\
\hline & & $\begin{array}{l}\text { "Importance of environment } \\
\text { compatible approach to tourism } \\
\text { development planning". }\end{array}$ & STPDM5 & 0.855 & & \\
\hline & & $\begin{array}{l}\text { "Emphasis on community } \\
\text { participatory process in } \\
\text { tourism planning". }\end{array}$ & STPDM6 & 0.896 & & \\
\hline & & $\begin{array}{l}\text { "Cooperation between public and } \\
\text { private sector for local }\end{array}$ & STPDM7 & 0.781 & & \\
\hline & & tourism development". & & & & \\
\hline & & $\begin{array}{c}\text { "Collaboration among public sector } \\
\text { units for local } \\
\text { tourism development" }\end{array}$ & STPDM8 & 0.837 & & \\
\hline & & $\begin{array}{l}\text { "Stewardship of the } \\
\text { natural environment". }\end{array}$ & STPDM9 & 0.891 & & \\
\hline & & $\begin{array}{l}\text { "Promotion of partnerships between } \\
\text { public and private stakeholders". }\end{array}$ & STPDM10 & 0.869 & & \\
\hline & & "Tourist destination communication". & STPDM11 & 0.846 & & \\
\hline & & $\begin{array}{c}\text { "Effectiveness of destination } \\
\text { management structure". }\end{array}$ & STPDM12 & 0.870 & & \\
\hline & & $\begin{array}{c}\text { "Public sector commitment to } \\
\text { tourism/hospitality education } \\
\text { and training". }\end{array}$ & STPDM13 & 0.807 & & \\
\hline & & $\begin{array}{l}\text { "Effectiveness in crafting } \\
\text { tourism experiences". }\end{array}$ & STPDM14 & 0.911 & & \\
\hline & & $\begin{array}{l}\text { "Tourism impacts management } \\
\text { and monitoring". }\end{array}$ & STPDM15 & 0.863 & & \\
\hline & & "Tourist guidance and information". & STPDM16 & 0.903 & & \\
\hline & & $\begin{array}{l}\text { "Promotion of partnerships among } \\
\text { local tourist businesses". }\end{array}$ & STPDM17 & 0.883 & & \\
\hline \multirow{6}{*}{$\begin{array}{l}\text { Sustainable Tourism } \\
\text { Development (STD) }\end{array}$} & \multirow{6}{*}{ [10] } & $\begin{array}{l}\text { "Tourism-based plans and } \\
\text { development to sustain local } \\
\text { socio-cultural values } \\
\text { and traditions". }\end{array}$ & STD1 & 0.868 & \multirow{6}{*}{0.831} & \multirow{6}{*}{0.773} \\
\hline & & $\begin{array}{l}\text { "Cultural exchanges between } \\
\text { natives and visitors". }\end{array}$ & STD2 & 0.745 & & \\
\hline & & $\begin{array}{l}\text { "Promotion of environmental } \\
\text { education and conservation". }\end{array}$ & STD3 & 0.812 & & \\
\hline & & $\begin{array}{l}\text { "Tourism planning initiatives to } \\
\text { develop local economy and } \\
\text { local employment". }\end{array}$ & STD4 & 0.835 & & \\
\hline & & $\begin{array}{l}\text { "Regulatory environmental } \\
\text { standards to reduce the negative } \\
\text { impacts of tourism". } \\
\text { "Tourism planning and }\end{array}$ & STD5 & 0.844 & & \\
\hline & & $\begin{array}{l}\text { development initiatives to promote } \\
\text { local products". }\end{array}$ & STD6 & 0.791 & & \\
\hline \multirow{5}{*}{$\begin{array}{l}\text { Destination Social } \\
\text { Responsibility (DSR) }\end{array}$} & \multirow{5}{*}{ [19] } & $\begin{array}{l}\text { "Island seems to include } \\
\text { environmental concerns in } \\
\text { its operations". }\end{array}$ & DSR1 & 0.873 & \multirow{5}{*}{0.826} & \multirow{5}{*}{0.795} \\
\hline & & $\begin{array}{l}\text { "Island seems to give back to the } \\
\text { local community". }\end{array}$ & DSR2 & 0.846 & & \\
\hline & & $\begin{array}{l}\text { "Island seems to be successful in } \\
\text { their profitability". }\end{array}$ & DSR3 & 0.877 & & \\
\hline & & $\begin{array}{l}\text { "Island seems to treat its } \\
\text { stakeholders well". }\end{array}$ & DSR4 & 0.790 & & \\
\hline & & $\begin{array}{l}\text { "Island seems to be based on ethical } \\
\text { values and beyond } \\
\text { legal obligations". }\end{array}$ & DSR5 & 0.852 & & \\
\hline
\end{tabular}


Table 2. Cont.

\begin{tabular}{|c|c|c|c|c|c|c|}
\hline Construct & Source & Item & Item Coding & Loading & Jöreskog's rho $\left(\rho_{c}\right)$ & AVE \\
\hline $\begin{array}{c}\text { Tourist Value } \\
\text { Orientation (TVO) }\end{array}$ & [31] & $\begin{array}{l}\text { "Tourists take a trip to get rid of all } \\
\text { the shackles of daily life and freely } \\
\text { enjoy the holidays". } \\
\text { "Tourists do not want to take an } \\
\text { extra burden on vacationing because } \\
\text { of environmental concerns". } \\
\text { "Tourists feel entitled to consume } \\
\text { the destination resources freely, as } \\
\text { They have paid for the holiday". } \\
\text { "Tourists feel unobligated to be } \\
\text { responsible for destination } \\
\text { environmental degradation given } \\
\text { their short stay". } \\
\text { "The destination environment is not } \\
\text { within Tourists personal influence } \\
\text { and control". }\end{array}$ & $\begin{array}{l}\text { TVO1 } \\
\text { TVO2 }\end{array}$ & $\begin{array}{l}0.838 \\
0.736 \\
0.859\end{array}$ & 0.775 & 0.751 \\
\hline
\end{tabular}

To determine non-response bias, the independent $t$-tests method was performed by comparing the first and last 25 respondents for all constructs [128,129]. The results showed an insignificant difference between the early 25 and late 25 responses, which reveals nonresponse bias. Besides, a common method bias test was conducted by using the collinearity approach $[130,131]$. The results revealed a satisfactory value of 2.563 for average full variance co-linearity inflation factor (AFVIF), which is less than 3.3. Thus, we established that there are no common bias issues.

Finally, all variables of the model were tested for discriminant validity. The FornellLarcker criterion was used to test discriminant validity, results revealed that the correlation between the constructs is less than the square root of the AVE on diagonal lines in the model, shown in Table 3, which means that all variables in the research model fulfill discriminant validity requirement [124]. Further, we examine discriminant validity using the Heterotrait-Monotrait criterion (HTMT), shown in Table 4. The results showed that HTMT value is smaller than 0.90 , which fulfills the required criteria [126]. Thus, the model revealed satisfactory results for both tests of discriminant validity.

Table 3. Fornell-Larcker criterion.

\begin{tabular}{lcccc}
\hline Construct & DSR & STPDM & STD & TVO \\
\hline DSR & 0.827 & & & \\
STPDM & 0.663 & 0.815 & & \\
STD & 0.512 & 0.478 & 0.794 & \\
TVO & 0.314 & 0.574 & 0.621 & 0.789 \\
\hline
\end{tabular}

Table 4. Heterotrait-Monotrait criterion.

\begin{tabular}{lcccc}
\hline Construct & DSR & STPDM & STD & TVO \\
\hline DSR & & & & \\
STPDM & 0.580 & & & \\
STD & 0.658 & 0.756 & & \\
TVO & 0.747 & 0.557 & 0.674 & \\
\hline
\end{tabular}

\subsection{Structural Model}

The SRMR was used for goodness of fit [132]. The SRMR value 0.061 was successfully obtained by the model, which fulfills a certain threshold value of $<0.08$, hence, empirical data perfectly fit the model. The coefficient of determination $\left(R^{2}\right)$ value is 0.371 , which means that 37.1 percent variance in STD is explained by the model. The value of StoneGeisser's $Q^{2}$ is obtained through the blindfolding procedure for the model. The obtained value 0.218 demonstrates that the model consists of predictive relevance, as it is higher than $0[133,134]$. 
Table 5 demonstrates the results of the structural model. Results reveal the existence of significant positive relationship between STPDM and STD where $b=0.269$, $t$-value $=4.319, p$-value $=0.000$ and $\mathrm{f}^{2}=0.085$, which reject null hypothesis 1 and support alternative hypothesis 1 . Additionally, finding reports that STPDM have significant positive relation with DSR, where $\mathrm{b}=0.265, t$-value $=6.291, p$-value $=0.000$ and $\mathrm{f}^{2}=0.154$ and DSR also have significant positive relation with STD, where $b=0.239, t$-value $=2.673$, $p$-value $=0.008$ and $\mathrm{f}^{2}=0.059$. Therefore, null hypotheses 2 and 3 were rejected and alternative hypotheses 2 and 3 were accepted.

Table 5. Results of structural model.

\begin{tabular}{lccccccc}
\hline Effect & $\boldsymbol{\beta}$ & $\mathbf{C I}(\mathbf{5} \% \mathbf{, 9 5} \boldsymbol{\mathbf { 9 }})$ & $\boldsymbol{t}$-Value & $\boldsymbol{p}$-Value & $\mathbf{f}^{\mathbf{2}}$ & $\mathbf{R}^{\mathbf{2}}$ & $\mathbf{Q}^{\mathbf{2}}$ \\
\hline STPDM $->$ STD & 0.269 & $(0.243,0.426)$ & 4.319 & 0.000 & 0.085 & 0.371 & 0.218 \\
STPDM -> DSR & 0.265 & $(0.114,0.307)$ & 6.291 & 0.000 & 0.154 & 0.316 & 0.180 \\
DSR $->$ STD & 0.239 & $(0.056,0.310)$ & 2.673 & 0.008 & 0.059 & & \\
TVO - > STD & -0.117 & $(-0.289,-0.088)$ & 3.946 & 0.000 & 0.070 & \\
STPDM $\times$ TVO -> STD & -0.007 & $(-0.138,0.124)$ & 0.760 & 0.448 & 0.000 & \\
DSR $\times$ TVO -> STD & 0.122 & $(0.014,0.210)$ & 2.219 & 0.027 & 0.016 & \\
\hline
\end{tabular}

Further, the study examines the moderating effect of TVO by applying a two-stage approach as recommended by Hair et al. [124]. The results revealed that interaction term of STPDM $*$ TVO- $>$ STD is not significant, where $b=-0.007, t$-value $=0.760, p$-value $=0.448$, $\mathrm{f}^{2}=0.000$. Thus, accepted null hypothesis 5 and rejected alternative hypothesis 5 . Further, the standardization of interaction variables reveals that the interaction term of DSR $^{*}$ TVO- $>$ STD is significant, where $\mathrm{b}=0.122, t$-value $=2.219, p$-value $=0.027$ and $\mathrm{f}^{2}=0.016$. The effect size $\left(\mathrm{f}^{2}\right)$ of the interaction term (DSR $\times$ TVO) is 0.016 , which indicates a medium effect. Subsequently, the significant interaction effect was plotted, shown in Figure 2, to better understand the deviations of DSR on STD [135]. The graph reveals that the relationship between DSR and STD is stronger in the presence of high TVO, shown in Figure 2. The nature of the results is highly implausible as the higher level of TVO theorized to degrade the connection between DSR and STD. For this reason, null hypothesis 6 was rejected and alternative hypothesis 6 was accepted.

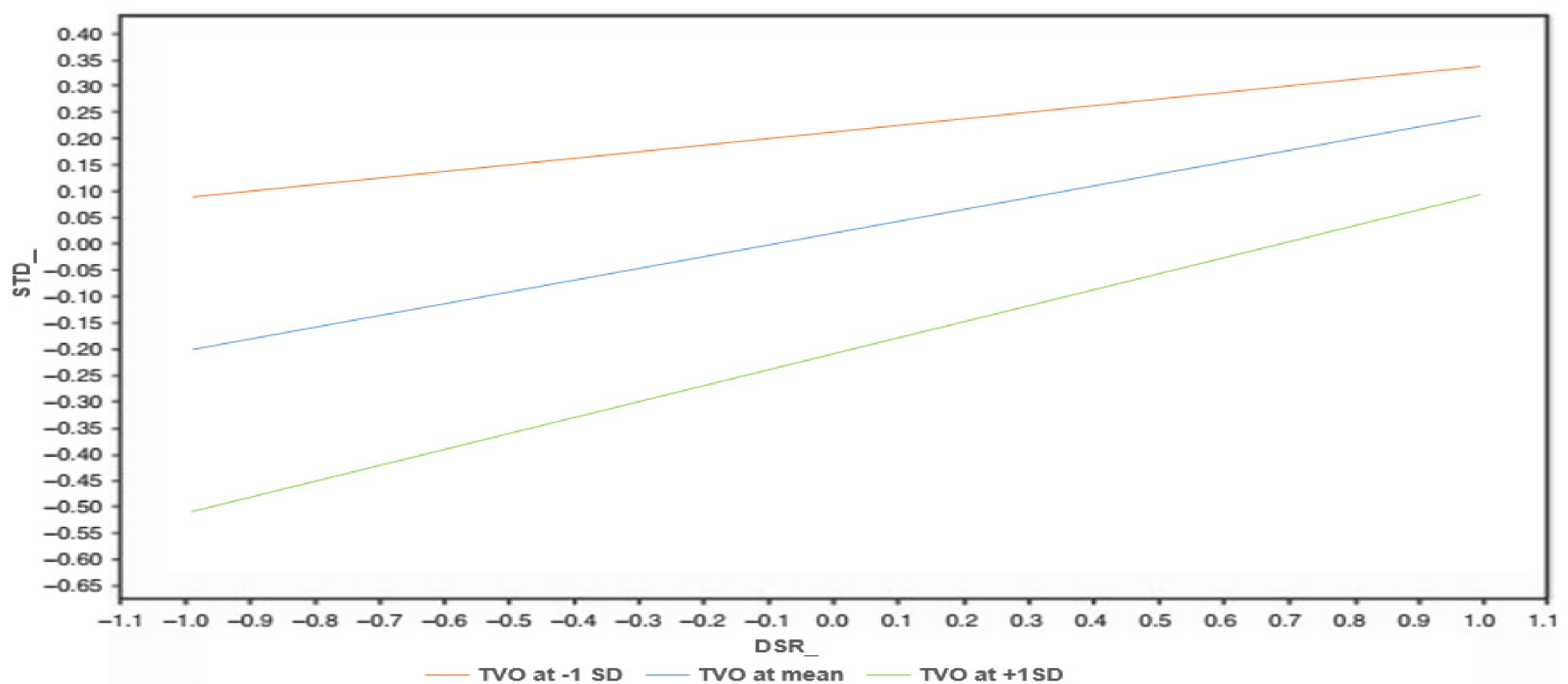

Figure 2. Moderating effect of TVO on DSR to sustainable tourism development. 


\subsection{Mediation Analysis}

This study applied the Nitzl et al. [136] analytical approach in conducting mediation analysis. Results of mediation analysis revealed that the values of $95 \%$ bias-corrected confidence interval (BCCI) did not straddle a 0 in between, which indicates the existence of a mediating effect of DSR, shown in Table 6. Further, to determine the degree of mediation, i.e., partial or full, the variance accounted for (VAF) index was used to examine the size of the indirect effect (STPDM -> DSR-> STD) related to the total effect (STPDM -> STD). The results reveal the existence of partial mediation, as the resulting VAF value of 24.86 percent falls within the range of 20-80 percent, which rejects null hypothesis 4 and partially supports alternative hypothesis 4 . Hence, the finding concludes that DSR partially mediates the relationship between STPDM and STD.

Table 6. Mediating effect analysis.

\begin{tabular}{|c|c|c|c|c|c|c|c|c|}
\hline Total Effect & BCCI & Path & $t$-Value & Indirect Effect & $95 \%$ BCCI & Path & $t$-Value & VAF \\
\hline STPDM -> STD & $(0.167 ; 0.396)$ & $0.358 *$ & 4.981 & STPDM $->$ DSR $->$ STD & $(0.011 ; 0.129)$ & $0.089 *$ & 2.314 & $24.86 \%$ \\
\hline
\end{tabular}

Lastly, the study conducted a post hoc test suggested by Hayes [137] to analyze the conditional indirect effect by using PROCESS Macro. The PLS algorithm was used to compute latent variable scores through SmartPLS 3.2.8, then extract as the input for the PROCESS Macro, shown in Table 7. The finding shows that conditional indirect effect has contained a 0 in between the values of $95 \%$ BCCI, which reveals the absence of a conditional indirect effect [138].

Table 7. Moderated mediation index.

\begin{tabular}{ccccc}
\hline \multicolumn{5}{c}{ 95\% BCCI } \\
\hline Mediating Variable & SE & Index & Lower & Upper \\
\hline DSR & 0.0361 & -0.004 & -0.0720 & 0.0724 \\
\hline
\end{tabular}

\section{Discussion}

This study found that STPDM significantly supports STD. Effective destination management and policy encourage a responsible exchange of resources between stakeholders, which contributes to STD. In this sense, STD potentially provides economic benefits to local communities, minimizes environmental and social repercussions. Policy and management are crucial for STD [76]. Hence, this study suggests that sustainable tourism policies, planning, management, and monitoring ultimately improve the living standard of communities through STD. STPDM is positively associated with DSR. Previous studies also support that economic benefits to local communities and the minimization of negative environmental and socio-cultural effects should be complementary objectives in all types of destinations, and it is critical to design and implement sustainable tourism policies to manage and control tourism destinations' activities [21,24]. As a result of considering stakeholders' interests, ST predicts that the destination will be more effective, sustainable, and manageable $[63,139]$. In line with ST, DMOs should communicate with the local community, as well as the tourists, to connect and coordinate the diverse interests of stakeholders within a destination in order to develop a quality and recognizable destination image, to achieve market excellence and long-term competitiveness, and to ensure the destination's sustainable development. By educating and engaging the local community, the tourism industry will be strengthened. Additionally, it will provide a better understanding of the perceived and actual consequences of tourism on the community. Hence, sustainable management of tourism destinations can contribute to long-term environmental, social, economic development, and can also provide an improved tourism experience. Further, DSR practices stimulate communal tourism activities, public relationships, environmental initiatives, and sustainability management [96]. 
We report a significant positive relationship between DSR and support for STD. Therefore, our findings are consistent with previous work [19], as socially responsible practices promote community support for tourism development. Previous studies $[15,17,53]$ also support that DSR improves destination competitiveness and promotes sustainable tourist development. From the perspective of SET, support for STD is an exchange interaction of the communities to seek something of value $[10,52]$. Additionally, this study found that DSR partially mediates the relationship between STPDM and STD. Therefore, STPDM is positively linked with DSR, which subsequently improves STD.

Furthermore, this study proposed TVO as a boundary condition, suggesting that both STPDM and DSR influence STD. Though, findings reject the theorized moderating role of TVO in the sustainable tourism model. The results report no moderation effect of TVO on STPDM and STD relationship. Wu and Geng [140] propose that tourists' anti-environmental behaviors can be detrimental to STD. However, results of the present study did not provide sufficient evidence to indicate a moderation effect of TVO on STD in presence of STPDM. The results indicate that the STD effect derived from STPDM is highly stable and its positive power is barely subject to moderation. It may also indicate that tourists with a strong affinity toward nature are less likely to harm the environment [141-144]. Even researchers claim that anti-environmental behavior brings about unethical behavior [145], whereas pro-environmental behavior is correlated with pro-social behavior and ethical behavior [146,147].

Further, the findings reveal that the DSR and STD relation becomes stronger when TVO is high. This may be attributed to tourists' tendency to separate their behavior from tourism motives in sustainable destinations. According to previous studies, different social values and a vocational mindset create an adverse effect on tourists' eco-friendly attitudes, however, lack of information, policies, and sustainable infrastructure negatively affect tourists' behaviors $[98,99]$. Consistent with these findings, tourists' eco-friendly attitudes can be improved through stimulating affiliation to the destination by providing frequent sustainable tourism experiences. Other factors that can enhance eco-friendly behavior are appropriate provision of environmentally friendly information, tourism products, and infrastructure [98]. Additionally, SET supports the concepts of costs, benefits, and reciprocity between people involved in a social relationship. Thus, tourists may resort to pro-environmental behavior to deal with sustainable destinations. Besides, effective destination management may simply dilute the effect of TVO and engage in STD as a coping mechanism [19].

Aside from that, the current COVID-19 epidemic is impacting the tourism sector, raising new challenges for sustainable tourism development. One of the major challenges for global sustainable tourism will be to maintain activity in wealthy nations while bringing activity to poor countries, some of which are excessively reliant on the tourism industry and markets [148]. Travel and tourism will transform in a post-Covid world due to tourists' choice, destination availability, and regulatory change [149]. Thus, these concerns should be considered in future research creating sustainable tourism development trends to avoid pandemics.

\subsection{Theoretical Implications}

The present paper offers valuable theoretical contributions in the area of STD. First, it confirms that STPDM antecedents of STD. This is an important finding in terms of destination management and its link to sustainability. It specifies that destinations can be developed in a sustainable way through sustainable destination policies, management structure, integrated approach, and monitoring. Previous studies [21,24] have examined STPDM; however, no specific study seems to have attempted to examine the relationship between STPDM and STD. 
Second, DSR holds the potential to influence tourism development [19], and the link between tourism and DSR has become a new heated research topic [28,29]. However, no study to date has examined DSR as an outcome of STPDM. Our research addresses this knowledge gap and demonstrates that STPDM is positively related to DSR, which results in enhanced communal support for tourism development.

Third, the study reveals that DSR positively supports STD. Perhaps more importantly, DSR perceived by residents can function as a social input in the process of social exchange. Thus, DSR forms perceived impact and then support for tourism development as a behavioral outcome, which is consistent with previous studies $[6,15,17]$.

\subsection{Managerial Implications}

We offer important implications for practitioners and policymakers for sustainable destination management. We provide a novel insight into the role of DSR that stakeholders' concerns in destination operations significantly improve communal support for STD. Hence managers should adopt a "win-win" approach by considering all stakeholders in the destination. This calls for an investment in DSR initiatives such as a social responsibility management fund that can be used for community development or to address local emergencies. Local tourism could benefit from a wider collaboration in form of the collective discussions between policymakers and businesses to adopt an integrated approach of tourism planning to minimize adverse social effects of tourism on local communities. Sustainable tourism is meant to protect the socio-cultural values and traditions and to encourage cultural exchange between residents and tourists, as well as to create employment opportunities and better economic conditions. Besides, sustainable tourism destination management and monitoring provide stewardship of the natural environment and effectively create a pleasant tourism experience.

DSR significantly encourages communal support for STD. Practitioners and policymakers should consider an environmental approach (e.g., initiating environmental protection awareness campaigns or creating environmental protection funds), and ethical values (e.g., cultural, political, and professional) beyond legal obligations in their operations to compensate local communities. Further, the COVID-19 pandemic has influenced tourists' choices and risk perceptions, as tourists consider visiting a destination with health regulatory laws that may impact future tourism development; thus, destination managers should implement infection monitoring programs and health regulatory measures to contribute to public health promotion in the immediate aftermath of the pandemic and beyond. Additionally, policymakers should organize campaigns to provide hospitality education and training regarding the importance of cultural identity, acknowledgment for different values, and cultural exchange awareness between host community and tourists to heighten support for STD. In line with prior literature, residents are much more concerned about their economic well-being [56]. Thus, the economic aspect in terms of working opportunities as well as living standards should be considered practically while maintaining the diversity of the destination in question. Further, practitioners could also share information about how tourism contributes to the communal tax base and encourages economic development.

Finally, TVO correlates with STD but shows no moderation on STPDM and STD relationship. This phenomenon explains the tendency of tourists to separate their behavior from tourism motives in control mechanisms. Besides, it was found that the strength of DSR and STD relationship increases when TVO is higher. A possible explanation is that DSR practices simply dilute the effect of TVO and engage in STD as a coping mechanism. Therefore, the proposed framework can be considered by policymakers and practitioners to enhance the STD of crowded tourism destinations by providing "green" infrastructure, such as waste recycling containers and eco-friendly transport to improve the environmentally friendly behavior of tourists. Hence, the framework can help policymakers to comprehend the requirements of sustainable tourism. 


\subsection{Limitations and Future Directions}

In this study, the data used for empirical analysis were collected from popular tourist destinations, hence, the findings are limited to highly crowded tourist destinations. Therefore, the study could be replicated by researchers in different geographic, social, and cultural scenarios. This study was based on a cross-sectional research design; therefore, a significant contribution for future research could be the collection and analysis of longitudinal data and adopting a mixed-method approach which could have yielded alternative results. Thus, the pivotal findings can be obtained by taking several implications into account due to the given magnitude of outcomes, opinions, and responses of other sustainability stakeholders. Furthermore, this study used a limited sample size for empirical analysis, however, combined with previous literature the data provide important preliminary empirical findings. Therefore, future research with larger sample size is needed to improve the precision of estimates. Moreover, it is advisable to utilize other variables related to tourism education for tourists in different languages for a better and friendly tourism experience $[150,151]$.

\section{Conclusions}

The present study contributes to the sustainability literature by reporting the unexplored relationships between sustainable tourism policy and destination management, destination social responsibility, tourist value orientation, and sustainable tourism development. The study attempts to depict the dependency of sustainable development of tourism on effective sustainable policies and management. As emerged from the tourism literature review, there is a lack of knowledge about the role of STPDM and DSR for STD in presence of anti-environmental behavior of tourists, and there were no prior frameworks systematically presenting these relationships. Moreover, as the globe grapples with the reality of the COVID-19 pandemic, there is a chance to reconsider the future of tourism and grasp the opportunities for development of sustainable tourism [148].

Sustainable development has enormous economic, environmental and social implications as a core principle of development. The development of the tourism industry is also tied with three aspects of sustainable development linked to the modern world. The analyses of new ways present in the modern world are important for the tourism industry, as global economic, social, and environmental mechanisms are expanding. It adopts that sustainable destination is best conceived of as an upper-level competence that involves the coordination of a range of different factors. STPDM and DSR intend to reduce adverse effects of tourism and tensions created by a complex interaction between tourists, environment, and host communities. Subsequently, development of sustainable tourism facilitates host community wellbeing, promotes sustainability education, and protects the environment, it also provides a better tourism experience, and promotes cultural exchange between tourists and natives. Tourists perform many activities that negatively influence destination sustainability. Hence, tourists' anti-environmental behavior needs to cope up with better management and planning strategies for sustainable development of tourism destinations.

This study addressed a research gap by establishing empirical evidence for the development of sustainable tourism through sustainable policies, management, and DSR. Additionally, research indicates that anti-environmental behavior of tourists can be coped up with effective sustainable management strategies. The finding of this study reveals that sustainable tourism policy and destination management empower local communities and facilitate tourist requirements via managing and controlling tourism destination activities. The results supported that STPDM positively and significantly influences STD. Moreover, DSR partially mediates the relationship between STPDM and STD. Although the theorized moderating effect of tourist value orientation was not supported, we yielded an interesting result: the relationship between destination social responsibility and sustainable tourism development becomes stronger when tourist value orientation is high. 
Author Contributions: Formal analysis, M.R.K. and M.F.A.; Funding acquisition, C.K.L. and K.L.T.; Investigation, M.R.K.; Methodology, H.U.R.K.; Project administration, M.F.A.; Software, H.U.R.K.; Supervision, C.K.L. and K.L.T.; Validation, C.K.L., K.L.T. and M.F.A.; Writing-original draft, M.R.K. and H.U.R.K.; Writing-review \& editing, M.R.K., H.U.R.K., C.K.L., K.L.T. and M.F.A. All authors have read and agreed to the published version of the manuscript.

Funding: This research was funded by the Wawasan Open University: Publicationfund-WOU-CeRi-002. Institutional Review Board Statement: Not applicable.

Informed Consent Statement: Not applicable.

Data Availability Statement: Not applicable.

Acknowledgments: The authors want to acknowledge the crucial role of participants, members of our research teams and all stakeholders involved in the data collection.

Conflicts of Interest: The authors declare no conflict of interest.

\section{References}

1. United Nations World Tourism Organization (WTO); United Nations Development Programme (UNDP). Tourism and the Sustainable Development Goals_Journey to 2030; United Nations World Tourism Organization (UNWTO): Madrid, Spain, 2017.

2. United Nations World Tourism Organization (UNWTO). International Tourism Highlights. 2019. Available online: https:/ / www.e-unwto.org/doi/pdf/10.18111/9789284421152 (accessed on 12 November 2019).

3. Dolezal, C.; Trupp, A.; Bui, H.T. Tourism and Development in Southeast Asia; Routledge: New York, NY, USA, 2020.

4. Roman, M.; Niedziółka, A.; Krasnodębski, A. Respondents' involvement in tourist activities at the time of the COVID-19 pandemic. Sustainability 2020, 12, 9610. [CrossRef]

5. Sharpley, R. Tourism and sustainable development: Exploring the theoretical divide. J. Sustain. Tour. 2000, 8, 1-19. [CrossRef]

6. Cheng, T.-M.; Wu, H.C.; Wang, J.T.-M.; Wu, M.-R. Community participation as a mediating factor on residents' attitudes towards sustainable tourism development and their personal environmentally responsible behaviour. Curr. Issues Tour. 2017, 22, 1764-1782. [CrossRef]

7. Gössling, S.; Scott, D.; Hall, M.C. Pandemics, tourism and global change: A rapid assessment of COVID-19. J. Sustain. Tour. 2020, 29, 1-20. [CrossRef]

8. Persson-Fischer, U.; Liu, S. The impact of a global crisis on areas and topics of tourism research. Sustainability 2021, 13, 906. [CrossRef]

9. Gursoy, D.; Chi, C.G.; Dyer, P. Locals' attitudes toward mass and alternative tourism: The case of Sunshine Coast, Australia. J. Travel Res. 2009, 49, 381-394. [CrossRef]

10. Eslami, S.; Khalifah, Z.; Mardani, A.; Streimikiene, D.; Han, H. Community attachment, tourism impacts, quality of life and residents' support for sustainable tourism development. J. Travel Tour. Mark. 2019, 36, 1061-1079. [CrossRef]

11. Lee, T.H. Influence analysis of community resident support for sustainable tourism development. Tour. Manag. 2013, 34, 37-46. [CrossRef]

12. Lee, T.H.; Jan, F.-H. Can community-based tourism contribute to sustainable development? Evidence from residents' perceptions of the sustainability. Tour. Manag. 2019, 70, 368-380. [CrossRef]

13. Nicholas, L.N.; Thapa, B.; Ko, Y.J. Residents' perspectives of a world heritage site: The pitons management area, St. Lucia. Ann. Tour. Res. 2009, 36, 390-412. [CrossRef]

14. Rey-Moreno, M.; Medina-Molina, C. Dual models and technological platforms for efficient management of water consumption. Technol. Forecast. Soc. Chang. 2020, 150, 119761. [CrossRef]

15. Sheldon, P.J.; Park, S.-Y. An exploratory study of corporate social responsibility in the U.S. travel industry. J. Travel Res. 2010, 50, 392-407. [CrossRef]

16. Park, S.; Song, S.; Lee, S. Corporate social responsibility and systematic risk of restaurant firms: The moderating role of geographical diversification. Tour. Manag. 2017, 59, 610-620. [CrossRef]

17. Su, L.; Swanson, S.R. The effect of destination social responsibility on tourist environmentally responsible behavior: Compared analysis of first-time and repeat tourists. Tour. Manag. 2017, 60, 308-321. [CrossRef]

18. Nunkoo, R.; Ramkissoon, H. Developing a community support model for tourism. Ann. Tour. Res. 2011, 38, 964-988. [CrossRef]

19. Su, L.; Huang, S.S.; Pearce, J. How does destination social responsibility contribute to environmentally responsible behaviour? A destination resident perspective. J. Bus. Res. 2018, 86, 179-189. [CrossRef]

20. Su, L.; Huang, S.; Huang, J. Effects of destination social responsibility and tourism impacts on residents' support for tourism and perceived quality of life. J. Hosp. Tour. Res. 2018, 42, 1039-1057. [CrossRef]

21. Goffi, G.; Cucculelli, M. Explaining tourism competitiveness in small and medium destinations: The Italian case. Curr. Issues Tour 2018, 22, 2109-2139. [CrossRef]

22. Byrd, E.T.; Bosley, H.E.; Dronberger, M.G. Comparisons of stakeholder perceptions of tourism impacts in rural eastern North Carolina. Tour. Manag. 2009, 30, 693-703. [CrossRef]

23. Yuksel, F.; Bramwell, B.; Yuksel, A. Stakeholder interviews and tourism planning at Pamukkale, Turkey. Tour. Manag. 1999, 20, 351-360. [CrossRef] 
24. Cucculelli, M.; Goffi, G. Does sustainability enhance tourism destination competitiveness? Evidence from Italian destinations of excellence. J. Clean. Prod. 2016, 111, 370-382. [CrossRef]

25. Eom, T.; Han, H.; Song, H. Discovering the perceived attributes of CBT destination travelers in South Korea: A mixed method approach. Tour. Manag. 2020, 77, 104013. [CrossRef]

26. Han, H.; Yu, J.; Lee, J.; Kim, W. Impact of hotels' sustainability practices on guest attitudinal loyalty: Application of loyalty chain stages theory. J. Hosp. Mark. Manag. 2019, 28, 905-925. [CrossRef]

27. Stylidis, D. Using destination image and place attachment to explore support for tourism development: The case of tourism versus non-tourism employees in EILAT. J. Hosp. Tour. Res. 2020, 44, 951-973. [CrossRef]

28. Hu, B.; Tuou, Y.; Liu, J. How does destination social responsibility impact residents' pro-tourism behaviors? The mediating role of place attachment. Sustainability 2019, 11, 3373. [CrossRef]

29. Su, L.; Swanson, S.R.; He, X. A scale to measure residents perceptions of destination social responsibility. J. Sustain. Tour. 2019, 28, 873-897. [CrossRef]

30. Ho, J.A.; Chia, K.W.; Ng, S.I.; Ramachandran, S. Problems and stakeholder responsibilities in island tourism: The case of Tioman Island in Malaysia. J. Hosp. Tour. Res. 2017, 41, 445-474. [CrossRef]

31. Qu, Y.; Xu, F.; Lyu, X. Motivational place attachment dimensions and the pro-environmental behaviour intention of mass tourists: A moderated mediation model. Curr. Issues Tour. 2017, 22, 197-217. [CrossRef]

32. Omar, S.I.; Othman, A.G.; Mohamed, B. The tourism life cycle: An overview of Langkawi Island, Malaysia. Int. J. Cult. Tour. Hosp. Res. 2014, 8, 272-289. [CrossRef]

33. Streimikiene, D.; Svagzdiene, B.; Jasinskas, E.; Simanavicius, A. Sustainable tourism development and competitiveness: The systematic literature review. Sustain. Dev. 2021, 29, 259-271. [CrossRef]

34. Choe, J.; Lugosi, P. Migration, tourism and social sustainability. Tour. Geogr. 2021, 1-8. [CrossRef]

35. Nathaniel, S.P.; Barua, S.; Ahmed, Z. What drives ecological footprint in top ten tourist destinations? Evidence from advanced panel techniques. Environ. Sci. Pollut. Res. 2021, 28, 38322-38331. [CrossRef]

36. Pitrelli, M.B.; Goel, S. After a Long Wait, Some of Southeast Asia's Most Popular Islands Are Reopening to Travelers. CNBC Travel. 2021. Available online: https://www.cnbc.com/2021/09/28/where-can-i-travel-in-southeast-asia-here-whats-openfor-tourists.html (accessed on 21 October 2021).

37. United Nations World Tourism Organization (UNWTO). Impact Assessment of the COVID-19 Outbreak on International Tourism. 2020. Available online: https://www.unwto.org/impact-assessment-of-the-covid-19-outbreak-on-internationaltourism (accessed on 11 May 2021).

38. Britton, S.G. The political economy of tourism in the third world. Ann. Tour. Res. 1982, 9, 331-358. [CrossRef]

39. Telfer, D.J.; Sharpley, R. Tourism and Development in the Developing World; Routledge: Abingdon, UK, 2008.

40. Chan, R.; Bhatta, K.D. Ecotourism planning and sustainable community development: Theoretical perspectives for Nepal. S. Asian J. Tour. Herit. 2013, 6, 69-96.

41. Lélé, S.M. Sustainable development: A critical review. World Dev. 1991, 19, 607-621. [CrossRef]

42. Warren, A. Comments on indigenous and scientific knowledge: Some critical comments. Indig. Knowl. Dev. Monit. 1996, 4, 13-14.

43. Mbaiwa, J.E. The socio-economic and environmental impacts of tourism development on the Okavango Delta, north-western Botswana. J. Arid. Environ. 2003, 54, 447-467. [CrossRef]

44. Bramwell, B.; Lane, B. Sustainable tourism: An evolving global approach. J. Sustain. Tour. 1993, 1, 1-5. [CrossRef]

45. Khan, H.R.; Lim, C.; Ahmed, M.; Tan, K.; Bin Mokhtar, M. Systematic review of contextual suggestion and recommendation systems for sustainable e-tourism. Sustainability 2021, 13, 8141. [CrossRef]

46. Ahmed, M.F.; Bin Mokhtar, M.; Lim, C.K.; Hooi, A.W.K.; Lee, K.E. Leadership roles for sustainable development: The case of a Malaysian green hotel. Sustainability 2021, 13, 260. [CrossRef]

47. World Commission on Environment and Development (WCED). Our Common Future; Oxford University Press: Oxford, UK, 1987.

48. Woosnam, K.M.; Aleshinloye, K.D. Can tourists experience emotional solidarity with residents? Testing Durkheim's model from a new perspective. J. Travel Res. 2012, 52, 494-505. [CrossRef]

49. Pearce, P.L.; Moscardo, G.; Ross, G.F. Tourism Community Relationships; Emerald Publishing Limited: London, UK, 1996.

50. England, J.L.; Albrecht, S.L. Boomtowns and social disruption. Rural Sociol. 1984, 49, $230-246$.

51. Ap, J. Residents' perceptions on tourism impacts. Ann. Tour. Res. 1992, 19, 665-690. [CrossRef]

52. Strzelecka, M.; Boley, B.B.; Strzelecka, C. Empowerment and resident support for tourism in rural Central and Eastern Europe (CEE): The case of Pomerania, Poland. J. Sustain. Tour. 2017, 25, 554-572. [CrossRef]

53. Su, L.; Wang, L.; Law, R.; Chen, X.; Fong, D. Influences of destination social responsibility on the relationship quality with residents and destination economic performance. J. Travel Tour. Mark. 2017, 34, 488-502. [CrossRef]

54. Gursoy, D.; Zhang, C.; Chi, O.H. Determinants of locals' heritage resource protection and conservation responsibility behaviors. Int. J. Contemp. Hosp. Manag. 2019, 31, 2339-2357. [CrossRef]

55. Mathew, P.V.; Sreejesh, S. Impact of responsible tourism on destination sustainability and quality of life of community in tourism destinations. J. Hosp. Tour. Manag. 2017, 31, 83-89. [CrossRef]

56. Qiu, H.; Fan, D.X.F.; Lyu, J.; Lin, P.M.C.; Jenkins, C.L. Analyzing the economic sustainability of tourism development: Evidence from Hong Kong. J. Hosp. Tour. Res. 2019, 43, 226-248. [CrossRef]

57. Gursoy, D.; Rutherford, D.G. Host attitudes toward tourism: An improved structural model. Ann. Tour. Res. 2004, 31, 495-516. [CrossRef] 
58. Swangjang, K.; Kornpiphat, P. Does ecotourism in a Mangrove area at Klong Kone, Thailand, conform to sustainable tourism? A case study using SWOT and DPSIR. Environ. Dev. Sustain. 2021, 23, 15960-15985. [CrossRef]

59. Choi, H.C.; Murray, I. Resident attitudes toward sustainable community tourism. J. Sustain. Tour. 2010, 18, 575-594. [CrossRef]

60. Islam, M.; Zhang, J.; Hasan, N. Assessing the adoption of sustainability practices in tourism industry: Insights from a developing country. Bottom Line 2019, 33, 94-115. [CrossRef]

61. Carneiro, M.J.; Eusébio, C. Host-tourist interaction and impact of tourism on residents' quality of life. Tour. Manag. Stud. 2015, 11, 25-34.

62. Hsu, C.-Y.; Chen, M.-Y.; Yang, S.-C. Residents' attitudes toward support for island sustainable tourism. Sustainability 2019, 11, 5051. [CrossRef]

63. Freeman, R.E. Strategic Management: A Stakeholder Approach; Cambridge University Press: Cambridge, UK, 1984.

64. Byrd, E.T. Stakeholders in sustainable tourism development and their roles: Applying stakeholder theory to sustainable tourism development. Tour. Rev. 2007, 62, 6-13. [CrossRef]

65. Hörisch, J.; Freeman, R.E.; Schaltegger, S. Applying stakeholder theory in sustainability management: Links, similarities, dissimilarities, and a conceptual framework. Organ. Environ. 2014, 27, 328-346. [CrossRef]

66. Easterling, D.S. The residents' perspective in tourism research: A review and synthesis. J. Travel Tour. Mark. 2005, 17, 45-62. [CrossRef]

67. Jaafar, M.; Rasoolimanesh, S.M.; Ismail, S. Perceived sociocultural impacts of tourism and community participation: A case study of Langkawi Island. Tour. Hosp. Res. 2017, 17, 123-134. [CrossRef]

68. Sautter, E.T.; Leisen, B. Managing stakeholders a tourism planning model. Ann. Tour. Res. 1999, 26, 312-328. [CrossRef]

69. Jamal, T.; Getz, D. Collaboration theory and community tourism planning. Ann. Tour. Res. 1995, 22, 186-204. [CrossRef]

70. Croes, R. Measuring and explaining competitiveness in the context of small island destinations. J. Travel Res. 2010, 50, 431-442. [CrossRef]

71. Morrison, A. Destination management and destination marketing: The platform for excellence in tourism destinations. Tour. Trib. 2013, 28, 6-9.

72. Mill, R.; Morrison, A. The Tourism System, 7th ed.; Kendall Hunt Publishing: Dubuque, IA, USA, 2012.

73. Cvelbar, K.L.; Dwyer, L.; Koman, M.; Mihalič, T. Drivers of destination competitiveness in tourism: A global investigation. J. Travel Res. 2016, 55, 1041-1050. [CrossRef]

74. Dwyer, L.; Livaic, Z.; Mellor, R. Competitiveness of Australia as a tourist destination. J. Hosp. Tour. Manag. 2003, 10, 60-79.

75. Ritchie, J.R.B.; Crouch, G.I. The Competitive Destination: A Sustainable Tourism Perspective; Cabi Publishing: Wallingford, UK, 2003.

76. Kastenholz, E. 'Management of demand' as a tool in sustainable tourist destination development. J. Sustain. Tour. 2004, 12, 388-408. [CrossRef]

77. Heath, E. Towards a model to enhance destination competitiveness: A Southern African perspective. J. Hosp. Tour. Manag. 2002, 10, 124-141.

78. Enright, M.J.; Newton, J. Tourism destination competitiveness: A quantitative approach. Tour. Manag. 2004, 25, 777-788. [CrossRef]

79. Gursoy, D.; Jurowski, C.; Uysal, M. Resident attitudes: A structural modeling approach. Ann. Tour. Res. 2002, 29, 79-105. [CrossRef]

80. Hwang, D.; Chi, S.H.; Lee, B. Collective action that influences tourism: Social structural approach to community involvement. J. Hosp. Tour. 2013, 40, 497-515. [CrossRef]

81. Sutawa, G.K. Issues on Bali tourism development and community empowerment to support sustainable tourism development. Procedia Econ. Financ. 2012, 4, 413-422. [CrossRef]

82. Falatoonitoosi, E.; Schaffer, V.; Kerr, D. Does sustainable tourism development enhance destination prosperity? J. Hosp. Tour. Res. 2021. [CrossRef]

83. De Keyser, R.; Vanhove, N.; Vanhove, N. The competitive situation of tourism in the Caribbean area methodological approach. Tour. Rev. 1994, 49, 19-22. [CrossRef]

84. Buhalis, D. Marketing the competitive destination of the future. Tour. Manag. 2000, 21, 97-116. [CrossRef]

85. Bornhorst, T.; Ritchie, J.B.; Sheehan, L. Determinants of tourism success for DMOs \& destinations: An empirical examination of stakeholders' perspectives. Tour. Manag. 2010, 31, 572-589. [CrossRef]

86. Harrill, R. Residents' attitudes toward tourism development: A literature review with implications for tourism planning. J. Plan. Lit. 2004, 18, 251-266. [CrossRef]

87. Hall, C.M. Policy learning and policy failure in sustainable tourism governance: From first- and second-order to third-order change? J. Sustain. Tour. 2011, 19, 649-671. [CrossRef]

88. Dredge, D. Are DMOs on a path to redundancy? Tour. Recreat. Res. 2016, 41, 348-353. [CrossRef]

89. Pearce, D. Destination management in New Zealand: Structures and functions. J. Destin. Mark. Manag. 2015, 4, 1-12. [CrossRef]

90. United Nations World Tourism Organization (UNWTO). UNWTO Annual Report 2016. 2016. Available online: https://www. unwto.org/archive/global/publication/unwto-annual-report-2016 (accessed on 16 May 2019).

91. Andereck, K.L.; Valentine, K.M.; Knopf, R.C.; Vogt, C.A. Residents' perceptions of community tourism impacts. Ann. Tour. Res. 2005, 32, 1056-1076. [CrossRef]

92. Grilli, G.; Tyllianakis, E.; Luisetti, T.; Ferrini, S.; Turner, R.K. Prospective tourist preferences for sustainable tourism development in small island developing states. Tour. Manag. 2021, 82, 104178. [CrossRef]

93. Pan, S.-Y.; Gao, M.; Kim, H.; Shah, K.; Pei, S.-L.; Chiang, P.-C. Advances and challenges in sustainable tourism toward a green economy. Sci. Total Environ. 2018, 635, 452-469. [CrossRef] 
94. Gursoy, D.; Boğan, E.; Dedeoğlu, B.B.; Çalışkan, C. Residents' perceptions of hotels' corporate social responsibility initiatives and its impact on residents' sentiments to community and support for additional tourism development. J. Hosp. Tour. Manag. 2019, 39, 117-128. [CrossRef]

95. Su, L.; Huang, Y. How does perceived destination social responsibility impact revisit intentions: The mediating roles of destination preference and relationship quality. Sustainability 2018, 11, 133. [CrossRef]

96. Inoue, Y.; Lee, S. Effects of different dimensions of corporate social responsibility on corporate financial performance in tourismrelated industries. Tour. Manag. 2011, 32, 790-804. [CrossRef]

97. Lenzen, M.; Sun, Y.-Y.; Faturay, F.; Ting, Y.-P.; Geschke, A.; Malik, A. The carbon footprint of global tourism. Nat. Clim. Change 2018, 8, 522-528. [CrossRef]

98. Chubchuwong, M.; Beise-Zee, R.; Speece, M.W. The effect of nature-based tourism, destination attachment and property ownership on environmental-friendliness of visitors: A study in Thailand. Asia Pac. J. Tour. Res. 2014, 20, 656-679. [CrossRef]

99. Miller, G.; Rathouse, K.; Scarles, C.; Holmes, K.; Tribe, J. Public understanding of sustainable tourism. Ann. Tour. Res. 2010, 37, 627-645. [CrossRef]

100. Holden, A.; Lupton, K.; Slocum, S.L.; Kline, C. Experiencing and connecting to nature: An urban to rural association. In Linking Urban and Rural Tourism: Strategies in Sustainability; Centre for Agriculture and Bioscience International (CABI): Wallingford, UK, 2017; pp. 20-32.

101. Mannell, R.C.; Iso-Ahola, S.E. Psychological nature of leisure and tourism experience. Ann. Tour. Res. 1987, 14, 314-331. [CrossRef]

102. Becken, S. Tourists' perception of international air travel's impact on the global climate and potential climate change policies. J. Sustain. Tour. 2007, 15, 351-368. [CrossRef]

103. Bechara, A.; Damasio, A.R. The somatic marker hypothesis: A neural theory of economic decision. Games Econ. Behav. 2005, 52, 336-372. [CrossRef]

104. Luft, J.; Ingham, H. The Johari window: A graphic model of awareness in interpersonal relations. Hum. Relat. Train. News 1961, 5, 6-7.

105. Belias, D.; Velissariou, E.; Chondrogiannis, M.; Kyriakou, D.; Varsanis, K.; Vasiliadis, L.; Koustelios, A. Exploring insurance fraud and tourists' misbehaviour. In Tourism, Hospitality E Event Management; Springer: Cham, Switzerland, 2018 ; pp. 147-156.

106. Wan, L.C.; Hui, M.K.; Qiu, Y.C. Tourist misbehavior: Psychological closeness to fellow consumers and informal social control. Tour. Manag. 2021, 83, 104258. [CrossRef]

107. Zhang, C.X.; Pearce, P.; Chen, G. Not losing our collective face: Social identity and Chinese tourists' reflections on uncivilised behaviour. Tour. Manag. 2019, 73, 71-82. [CrossRef]

108. Kozak, M.; Tasci, A.D.A. Perceptions of foreign tourists by local service providers: The case of Fethiye, Turkey. Int. J. Tour. Res. 2005, 7, 261-277. [CrossRef]

109. Luo, X.; Brown, G.; Huang, S.S. Host perceptions of backpackers: Examining the influence of intergroup contact. Tour. Manag. 2015, 50, 292-305. [CrossRef]

110. Green, J.P.; Tonidandel, S.; Cortina, J.M. Getting through the gate: Statistical and methodological issues raised in the reviewing process. Organ. Res. Methods 2016, 19, 402-432. [CrossRef]

111. Yasir, M.A.; Amir, A.M.; Maelah, R.; Nasir, A.H.M. Establishing customer knowledge through customer accounting in tourism industry: A study of hotel sector in Malaysia. Asian J. Account. Gov. 2020, 14, 1-12. [CrossRef]

112. Hirschmann, R. Travel and Tourism in Malaysia-Statistics \& Facts. Statista. 2020. Available online: https://www.statista.com/ topics/5741/travel-and-tourism-in-malaysia/ (accessed on 16 May 2019).

113. Amran, H. Policy and planning of the tourism industry in Malaysia. In Proceedings of the 6th ADRF General Meeting, Bangkok, Thailand, 7-8 June 2004.

114. Ministry of Tourism, Arts and Culture (MOTAC). Pelan Eko-Pelancongan Kebangsaan (Ringkasan Eksekutif). Ministry of Tourism \& Culture, Malaysia. 1996. Available online: http:/ /www.motac.gov.my/en/download/category/17-pelan-eko-pelancongankebangsaan-1996 (accessed on 12 May 2019).

115. Ministry of Tourism, Arts and Culture (MOTAC). National Ecotourism Plan: 2016-2025; Ministry of Tourism \& Culture Malaysia: Putrajaya, Malaysia, 2016. Available online: http:/ / www.motac.gov.my/en/download/category/86-pelan-eko-pelancongankebangsaan-2016-2025 (accessed on 12 May 2019).

116. Ministry of Tourism, Arts and Culture (MOTAC). Ministry of Tourism art and Culture Malaysia. 2019. Available online: http:/ / www.motac.gov.my/en/check/tobtab?c=\&n=6\&v=160 (accessed on 12 May 2019).

117. Quinn, J.B. Managing innovation: Controlled chaos. Harv. Bus. Rev. 1985, 63, 73-84.

118. Bartlett, C.A.; Goshal, S. Release the entrepreneurial hostages from your corporate hierarchy. Strat. Leadersh. 1996, 24, 36-42. [CrossRef]

119. Kline, R.B. Principles and Practice of Structural Equation Modeling, 3rd ed.; The Guilford Press: New York, NY, USA, 2011.

120. Tabachnick, B.G.; Fidell, L.S.; Ullman, J.B. Using Multivariate Statistics; Pearson: New York, NY, USA, 2007.

121. Fan, Y.; Chen, J.; Shirkey, G.; John, R.; Wu, S.R.; Park, H.; Shao, C. Applications of structural equation modeling (SEM) in ecological studies: An updated review. Ecol. Process. 2016, 5, 1-12. [CrossRef]

122. Gefen, D.; Rigdon, E.E.; Straub, D. Editor's comments: An update and extension to SEM guidelines for administrative and social science research. MIS Q. 2011, 35, 3-14. [CrossRef]

123. Faul, F.; Erdfelder, E.; Lang, A.-G.; Buchner, A. G* Power 3: A flexible statistical power analysis program for the social, behavioral, and biomedical sciences. Behav. Res. Methods 2007, 39, 175-191. [CrossRef] [PubMed] 
124. Hair, J.F.; Hult, G.T.M.; Ringle, C.M.; Sarstedt, M. A Primer on Partial Least Squares Structural Equation Modeling (PLS-SEM), 2nd ed.; Sage: Thousand Oaks, CA, USA, 2017.

125. Dijkstra, T.K.; Henseler, J. Consistent and asymptotically normal PLS estimators for linear structural equations. Comput. Stat. Data Anal. 2015, 81, 10-23. [CrossRef]

126. Henseler, J.; Ringle, C.M.; Sarstedt, M. A new criterion for assessing discriminant validity in variance-based structural equation modeling. J. Acad. Mark. Sci. 2015, 43, 115-135. [CrossRef]

127. Carmines, E.G.; Zeller, R.A. Reliability and Validity Assessment; Sage Publications: Thousand Oaks, CA, USA, 1979.

128. Armstrong, J.S.; Overton, T.S. Estimating nonresponse bias in mail surveys. J. Mark. Res. 1977, 14, 396-402. [CrossRef]

129. Ghouri, A.; Mani, V.; Khan, M.R.; Khan, N.R.; Srivastava, A.P. Enhancing business performance through green human resource management practices: An empirical evidence from Malaysian manufacturing industry. Int. J. Prod. Perform. Manag. 2020, 69, 1585-1607. [CrossRef]

130. Kock, N. Common method bias: A full collinearity assessment method for PLS-SEM. In Partial Least Squares Path Modeling; Springer Science and Business Media LLC: Berlin/Heidelberg, Germany, 2017; pp. 245-257.

131. Podsakoff, P.M.; MacKenzie, S.B.; Lee, J.Y.; Podsakoff, N.P. Common method biases in behavioral research: A critical review of the literature and recommended remedies. J. Appl. Psychol. 2003, 88, 879. [CrossRef]

132. Henseler, J.; Hubona, G.; Ray, P.A. Using PLS path modeling in new technology research: Updated guidelines. Ind. Manag. Data Syst. 2016, 116, 2-20. [CrossRef]

133. Geisser, S. A predictive approach to the random effect model. Biometrika 1974, 61, 101-107. [CrossRef]

134. Stone, M. Cross-validatory choice and assessment of statistical predictions. J. R. Stat. Soc. Ser. B Stat. Methodol. 1974, 36, 111-133. [CrossRef]

135. Dawson, J.F. Moderation in management research: What, why, when, and how. J. Bus. Psychol. 2014, 29, 1-19. [CrossRef]

136. Nitzl, C.; Roldan, J.L.; Cepeda, G. Mediation analysis in partial least squares path modeling: Helping researchers discuss more sophisticated models. Ind. Manag. Data Syst. 2016, 116, 1849-1864. [CrossRef]

137. Hayes, A.F. Introduction to Mediation, Moderation, and Conditional Process Analysis; Guilford: New York, NY, USA, 2013.

138. Hayes, A.F. An index and test of linear moderated mediation. Multivar. Behav. Res. 2015, 50, 1-22. [CrossRef]

139. Freeman, R.E.; Wicks, A.C.; Parmar, B. Stakeholder theory and the corporate objective revisited. Organ. Sci. 2004, 15, 364-369. [CrossRef]

140. Wu, Z.; Geng, L. Traveling in haze: How air pollution inhibits tourists' pro-environmental behavioral intentions. Sci. Total Environ. 2020, 707, 135569. [CrossRef]

141. Davis, J.L.; Green, J.D.; Reed, A. Interdependence with the environment: Commitment, interconnectedness, and environmental behavior. J. Environ. Psychol. 2009, 29, 173-180. [CrossRef]

142. Dutcher, D.D.; Finley, J.C.; Luloff, A.; Johnson, J.B. Connectivity with nature as a measure of environmental values. Environ. Behav. 2007, 39, 474-493. [CrossRef]

143. Hoot, R.E.; Friedman, H. Connectedness and environmental behavior: Sense of interconnectedness and pro-environmental behavior. Int. J. Transpers. Stud. 2010, 30, 89-100.

144. Mayer, F.; Frantz, C.M. The connectedness to nature scale: A measure of individuals' feeling in community with nature. J. Environ. Psychol. 2004, 24, 503-515. [CrossRef]

145. Lu, J.G.; Lee, J.J.; Gino, F.; Galinsky, A.D. Polluted morality: Air pollution predicts criminal activity and unethical behavior. Psychol. Sci. 2018, 29, 340-355. [CrossRef]

146. Bamberg, S.; Möser, G. Twenty years after Hines, Hungerford, and Tomera: A new meta-analysis of psycho-social determinants of pro-environmental behaviour. J. Environ. Psychol. 2007, 27, 14-25. [CrossRef]

147. Steg, L.; Vlek, C. Encouraging pro-environmental behaviour: An integrative review and research agenda. J. Environ. Psychol. 2009, 29, 309-317. [CrossRef]

148. Romagosa, F. The COVID-19 crisis: Opportunities for sustainable and proximity tourism. Tour. Geogr. 2020, 22, 690-694. [CrossRef]

149. Spalding, M.; Burke, L.; Fyall, A. COVID-19: Implications for nature and tourism. Anatolia 2021, 32, 126-127. [CrossRef]

150. Sulaiman, M.Z. Creating favourable destination images across languages: Collaboration between tourism studies and translation studies? Curr. Issues Tour. 2020, 24, 1-4. [CrossRef]

151. Lam, J.M.; Ariffin, A.A.M. Do travel images affect international students' on-site academic value? New evidence from the Malaysia's 'higher edutourism' destination. J. Vacat. Mark. 2019, 25, 499-514. [CrossRef] 